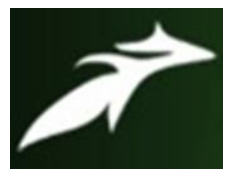

Satyam Kumar et al, International Journal of Advances in Agricultural Science and Technology,

Vol.8 Issue.8, August-2021, pg. 60-69

ISSN: 2348-1358

Impact Factor: 6.057

NAAS Rating: 3.77

\title{
Association between Knowledge, Adoption and Socio-Economic Profile of Maize Growers regarding Improved Maize Production Practices in Begusarai District of Bihar
}

\author{
Satyam Kumar ${ }^{1}$; Syed H. Mazhar ${ }^{2}$ \\ ${ }^{1}$ M.Sc. Ag. (Agricultural Extension and communication), SHUATS (Prayagraj) \\ ${ }^{2}$ Associate Professor, Department of Agriculture Extension and Communication, SHUATS (Prayagraj) \\ Author's e-mail: satyamkumar0047@gmail.com
}

DOI: 10.47856/ijaast.2021.v08i8.006

\begin{abstract}
The present study on socio-economic profile of the respondents and determine the level of knowledge and adoption in improved maize cultivation practices as enterprises. Begusarai district of Bihar is selected purposively for the present study, because there were large number of maize farmers in the district and also the researcher knows about the area and well conversant with language, geographical, agricultural and other aspect of the area. There are 18 blocks in the selected district out of that Teghra block is selected purposively for present study because there are large number of farmers. From that seven villages were randomly selected and a total of 120 maize farmers were selected using proportionate random sampling method. a comprehensive structured interview schedule covering all aspects of the improved maize production practices was prepared. The items included in the interview schedule were structured questions and objective type questions which were suitable to all categories of respondents. The data was collected from them, analyzed using MS-excel and the finding of the study has been given below. Majority of the respondents possessed middle level of innovativeness and economic motivation and high level of decision making ability and risk orientation. The overall knowledge an adoption level of the maize farmers was found under medium level. The local extension officials along with scientists should take appropriate knowledge promotional strategies such as training, demonstrations, exhibitions, etc., to impart cent per cent knowledge level and to increase the extent of adoption among the respondents.
\end{abstract}

Keywords: Improved maize production practices, Bihar, Maize growers, Knowledge and Adoption. 


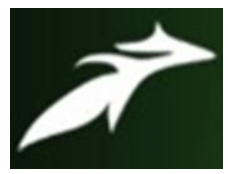

Satyam Kumar et al, International Journal of Advances in Agricultural Science and Technology,

Vol.8 Issue.8, August-2021, pg. 60-69

ISSN: 2348-1358

Impact Factor: 6.057

NAAS Rating: 3.77

\section{Introduction:}

Agriculture is the primary sector of economy and primary source of livelihood for about $58 \%$ of Indian population. At the time of Indian independence this sector had biggest share in the gross domestic products of India. Currently it contributes only 19\% of Indian GDP at current prices. India production of food grain has been increasing every year, and India is among the top producer of several crops such as rice, wheat, maize, pulses, sugarcane, cotton etc. Maize or Indian corn (called corn in some countries) is Zea mays, a member of the grass family Poaceae. It is a cereal grain which was first grown by people in ancient Central America. Approximately, 1 billion tonnes are harvested every year. Maize in India, contributes nearly $9 \%$ in the national food basket. In addition to staple food for human being and quality feed for animals, maize serves as a basic raw material as an ingredient to thousands of industrial products that includes starch, oil, protein, alcoholic beverages, food sweeteners, pharmaceutical, cosmetic, film, textile, gum, package and paper industries etc. Indian farmers are becoming more and more conscious of new agricultural technology (Akshaykumar 2021) and moving toward from the age-old, traditional to scientific farming (Kumar 2021). The forces of tradition, however, still continue to influence the rate of change resulting in a different adoption of various innovations introduced among the farming communities (Mandal B 2010).It has been observed that even cultivators with sound economic condition, social trading and some formal education are sometimes indifferent to adoption of some the newly evolved strains (Rajanendra Kumar 2002). A cursory review of researchers which have been conducted in the field of adoption of improved farm practices might suggest that with all that has been done (Sunil arya 2012), there is scarcely any need for further study on the subject but a critical analysis of the solution reveals that whereas abundant information is available on the relationship of some factors to the adoption of some practices (Venkatalakshmi 2020), others are comparatively unexplored amongst which constraints of improved farm practices occupying an important place. Keeping all those researchable issues in mind, the following specific objectives were formulated for the study.

- To ascertain the socio-economic profile of the respondents.

- To determine the level of knowledge and adoption in improved maize cultivation practices as enterprises. 


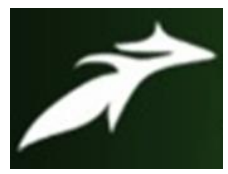

Satyam Kumar et al, International Journal of Advances in Agricultural Science and Technology, Vol.8 Issue.8, August-2021, pg. 60-69

ISSN: 2348-1358

Impact Factor: 6.057

NAAS Rating: 3.77

\section{Methodology:}

Begusarai lies in the middle of the mid Ganga plain and generally has low lying terrain with south to south easterly slope. Begusarai is basically divided in three flood plains namely: 1) Ganga flood plain 2) Burhi gandak flood plain 3) Kareha-Bagmati flood plain. As per 2011 census Begusarai Municipal Corporation had a total population of 251,136 , out of which 133,931 were males and 117,205 were females with sex ratio at 894 . The literacy rate is $63.87 \%$. Begusarai average annual rainfall $1285 \mathrm{~mm}$, and the climate is warm and temperate. Major soils are sandy soils, coarse sandy loam soils, fine sandy loam soils, clayey soil and saline soil. Begusarai district of Bihar is selected purposively for the present study, because there were large number of maize farmers in the district and also the researcher know about the area and well conversant with language, geographical, agricultural and other aspect of the area. There are 18 blocks in the selected district out of that Teghra block is selected purposively for present study because there are large number of farmers. There are 72 villages in Teghra block out of that 7 villages (Ayodhya, Daniyalpur, Dularapur, Pidhauli, Madhurapur, Hasanpur and Marseti) selected randomly based on the maximum number of farmers. Total of 120 maize farmers were selected by purposive sampling method. Considering the objectives and the variables selected for the study, a comprehensive structured interview schedule covering all aspects of the improved maize production practices was prepared. The items included in the interview schedule were structured questions and objective type questions which were suitable to all categories of respondents. The data was collected from them analyzed using MS-excel and the finding of the study has been given below.

\section{Results and Discussion:}

Table 01: Socio-Economic profile characters of the respondents

\begin{tabular}{|c|l|c|c|}
\hline S. No. & \multicolumn{1}{|c|}{ Socio-Economic profile characters } & Number & Per cent \\
\hline $\mathbf{1 .}$ & Age & 28 & 23.34 \\
\hline & Young & 67 & 55.83 \\
\hline & Middle & 25 & 20.83 \\
\hline & Old & 11 & 09.17 \\
\hline $\mathbf{2 .}$ & Educational status & 12 & 10.00 \\
\hline & Illiterate & 25 & 20.83 \\
\hline & Functionally literate & \multicolumn{2}{|l|}{} \\
\hline & Primary school education
\end{tabular}




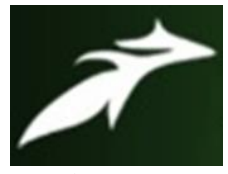

Satyam Kumar et al, International Journal of Advances in Agricultural Science and Technology, Vol.8 Issue.8, August-2021, pg. 60-69

ISSN: 2348-1358 Impact Factor: 6.057 NAAS Rating: 3.77

\begin{tabular}{|c|c|c|c|}
\hline & Middle school education & 31 & 25.83 \\
\hline & High school education & 13 & 10.83 \\
\hline & Higher secondary education & 19 & 15.84 \\
\hline & Collegiate education & 09 & 07.50 \\
\hline \multirow[t]{5}{*}{3.} & \multicolumn{3}{|l|}{ Occupational status } \\
\hline & Agriculture alone & 75 & 62.50 \\
\hline & Agriculture + Business & 14 & 11.67 \\
\hline & Agriculture + Labour & 25 & 20.83 \\
\hline & Agriculture+ Government / Private services & 06 & 05.00 \\
\hline \multirow[t]{4}{*}{4.} & Size of land holding & & \\
\hline & Up to 2.5 acres & 26 & 21.67 \\
\hline & 2.5 acres to 5 acres & 73 & 60.83 \\
\hline & More than 5 acres & 21 & 17.50 \\
\hline \multirow[t]{4}{*}{5.} & \multicolumn{3}{|l|}{ Family size } \\
\hline & Small & 54 & 45.00 \\
\hline & Medium & 45 & 37.50 \\
\hline & Big & 21 & 17.50 \\
\hline \multirow[t]{4}{*}{6.} & \multicolumn{3}{|l|}{ Farming Experience } \\
\hline & Low & 34 & 28.33 \\
\hline & Medium & 60 & 50.00 \\
\hline & High & 26 & 21.66 \\
\hline \multirow[t]{4}{*}{7.} & \multicolumn{3}{|l|}{ Annual Income } \\
\hline & Low (< Rs. 50,000) & 35 & 29.17 \\
\hline & Medium (Rs. 50,001 - Rs. 1,00,000) & 54 & 45.00 \\
\hline & High (>Rs. $1,00,000)$ & 31 & 25.83 \\
\hline \multirow[t]{4}{*}{8.} & \multicolumn{3}{|l|}{ Material Possession } \\
\hline & Low & 78 & 65.00 \\
\hline & Medium & 33 & 27.50 \\
\hline & High & 09 & 07.50 \\
\hline \multirow[t]{4}{*}{9.} & \multicolumn{3}{|l|}{ Extension agent contact } \\
\hline & Low & 41 & 34.16 \\
\hline & Medium & 53 & 44.17 \\
\hline & High & 26 & 21.67 \\
\hline \multirow[t]{4}{*}{10.} & \multicolumn{3}{|l|}{ Social participation } \\
\hline & Low & 56 & 46.67 \\
\hline & Medium & 45 & 37.50 \\
\hline & High & 19 & 15.83 \\
\hline \multirow[t]{4}{*}{11.} & \multicolumn{3}{|l|}{ Mass media exposure } \\
\hline & Low & 28 & 23.33 \\
\hline & Medium & 72 & 60.00 \\
\hline & High & 20 & 16.67 \\
\hline 12. & \multicolumn{3}{|l|}{ Source of Information } \\
\hline
\end{tabular}




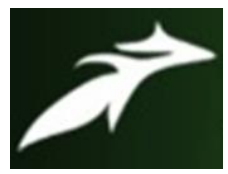

Satyam Kumar et al, International Journal of Advances in Agricultural Science and Technology, Vol.8 Issue.8, August-2021, pg. 60-69

ISSN: 2348-1358

Impact Factor: 6.057

NAAS Rating: $\mathbf{3 . 7 7}$

\begin{tabular}{|l|l|r|r|}
\hline & Government Extension officials & 65 & 54.17 \\
\hline & Private Extension staffs & 19 & 15.83 \\
\hline & NGOs & 00 & 00.00 \\
\hline & KVK & 02 & 01.67 \\
\hline & Neighbors/Friends & 15 & 12.50 \\
\hline & Fellow farmers & 11 & 09.17 \\
\hline & Social Media & 08 & 06.67 \\
\hline 13. & Innovativeness & 54 & 28.33 \\
\hline & Low & 34 & 45.00 \\
\hline & Medium & 32 & 26.67 \\
\hline & High & 32 & 26.67 \\
\hline 14. & Decision making ability & 43 & 35.83 \\
\hline & Low & 45 & 37.50 \\
\hline & Medium & 29 & 24.17 \\
\hline & High & 44 & 36.67 \\
\hline 15. & Risk orientation & 47 & 39.17 \\
\hline & Low & 39 & 32.50 \\
\hline & Medium & 51 & 42.50 \\
\hline & High & 30 & 25.00 \\
\hline 16. & Economic motivation & \multicolumn{2}{|l|}{} \\
\hline & Low & \multicolumn{2}{|l|}{} \\
\hline & Medium & \\
\hline & High & & \\
\hline
\end{tabular}

From table 01 , more than half $(55.83 \%)$ of the maize farmers belong to the middle age group, followed by 23.33 per cent of the maize growers fell in to the young age category and one fifth $(20.83 \%)$ of the maize farmers were old aged. It could be interpreted that nearly three-fourth of the farmers were under 45 age. It was evident from the table that, middle school education (25.83\%); primary school education (20.83\%); higher secondary school education (15.84\%); high school education (10.83\%), functionally literate $(10.00 \%)$; illiterate $(09.17 \%)$ and collegiate education (07.50\%).Nearly two-third $(62.50 \%)$ of the maize farmers have doing agriculture alone as their occupation, followed by 20.83 per cent of the farmers took agriculture laborer profession, 11.67 per cent and 05.00 per cent of the maize growers have depended agriculture as a side stick along with business and government/private services respectively. More than three-fifth $(60.83 \%)$ of the maize farmers hold 2.5 to 5 acres of land and fall under small farmers category, whereas nearly one-fifth (21.67\%) of the farmers have less than 2.5 acres of land and 17.50 per cent of the maize growers had more than 5 acres of land. Higher percentage of the maize growers had small family (45.00\%), followed by medium (37.50\%) and big family (17.50\%).Half 


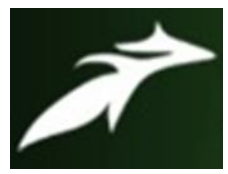

Satyam Kumar et al, International Journal of Advances in Agricultural Science and Technology,

Vol.8 Issue.8, August-2021, pg. 60-69

ISSN: 2348-1358

Impact Factor: 6.057

NAAS Rating: 3.77

$(50.00 \%)$ of the maize growers had medium level of experience in maize production, nearly 28.33 per cent of the farmers had low level of farming experience and famers who had high farming experience were 21.66 per cent in the study. More than half $(45.00 \%)$ of the maize farmers were having annual income of fifty thousand one rupees to one lakh rupees followed by 29.17 per cent of the maize farmers were having annual income of less than fifty thousand rupees and 25.83 per cent of maize farmers in the study area were having annual income of more than one lakh rupees.Majority (65.00\%) of the farmers possessed low farm materials, more than one-fourth $(27.50 \%)$ of the maize farmer's had medium possession of farm materials and 07.50 per cent of the farmers have high material possession. Higher percentage $(44.17 \%)$ of the maize farmers had medium level of contact with extension agent, more than one-third (34.16\%) of the maize farmer's contact with extension agents were in low level and 21.67 per cent of the maize farmers had high level of contact with extension agent. Majority (46.67\%) of the maize farmers had low social participation, subsequently 37.50 per cent of the maize growers had medium level of social participation and only 15.83 per cent of the maize growers had high level of social participation. Majority (60.00\%) of the maize farmers have been utilizing media at medium level. About 23.33 per cent maize farmers had low level of utilization of media and media platform had used at high level by 16.67 per cent of the maize farmers. More than half $(54.17 \%)$ of the farmers had depended on government extension officials as their source to get information about agriculture, followed by 15.83 per cent of the maize farmers hinge on their private extension staffs to know about latest agricultural information. About 12.50 and 09.17 per cent of the farmers had contingent on neighbors/friends and fellow farmers as their source of agricultural information respectively. Few (06.67\% and 01.67\%) of the farmers has used social media and KVK as their source of agricultural information. Majority (45.00\%) of the maize growers had middle level of innovativeness followed by 28.33 and 26.67 per cent of the users had low and high level of innovativeness respectively. Preponderance (37.50\%) of the respondents had high level of, followed by 35.83 per cent and 26.67 per cent of medium and low level decision making ability exposure respectively. Higher percentage $(39.17 \%)$ of the maize farmers had high level of risk bearing capacity, followed by 36.67 per cent and 24.17 per cent of the maize growers had medium and low level of risk bearing capacity the farmers respectively. Majority (42.50\%) of the maize farmers had medium level of economic motivation, followed by 32.50 per cent of maize growers had high level of economic motivation and only 25.00 per cent of the maize farmers had low level of economic motivation. 


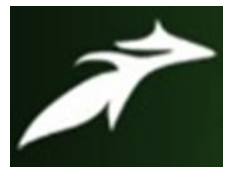

Satyam Kumar et al, International Journal of Advances in Agricultural Science and Technology, Vol.8 Issue.8, August-2021, pg. 60-69

ISSN: 2348-1358

Impact Factor: 6.057

NAAS Rating: 3.77

Table 02: Distribution of respondents according to their Knowledge and Adoption level

\begin{tabular}{|l|l|c|c|c|c|}
\hline \multirow{2}{*}{ S. No. } & \multirow{2}{*}{ Category } & \multicolumn{2}{c|}{ Knowledge } & \multicolumn{2}{c|}{ Adoption } \\
\cline { 3 - 6 } & & Number & Per cent & Number & Per cent \\
\hline 1. & Low & 35 & 29.17 & 15 & 12.50 \\
\hline 2. & Medium & 57 & 47.50 & 79 & 65.83 \\
\hline 3. & High & 28 & 23.33 & 26 & 21.66 \\
\hline 4. & Total & 120 & 100.00 & 120 & 100.00 \\
\hline
\end{tabular}

From table 02, Majority (47.50\%) of the maize growers had medium level of knowledge on improved maize cultivation practices, 29.17 per cent and 23.33 per cent of the maize growers had low and high level of knowledge on improved maize cultivation practices. Whereas, higher percentage of the maize growers (65.83\%) had medium level of adoption whereas 21.66 per cent of the farmers had high level of adoption of improved maize production technology and 12.50 per cent of the farmers had low level of adoption of improved maize production technologies.

Table.03. Association between the independent variables and knowledge level of the farmers about improved maize cultivation practices

\begin{tabular}{|c|l|l|}
\hline S. No. & \multicolumn{1}{|c|}{ Characteristics } & \multicolumn{1}{|c|}{ 'r' value } \\
\hline $\mathrm{X} 1$ & Age & 0.161 \\
\hline $\mathrm{X} 2$ & Educational status & $0.212^{*}$ \\
\hline $\mathrm{X} 3$ & Occupational status & 0.109 \\
\hline $\mathrm{X} 4$ & Family size & -0.041 \\
\hline $\mathrm{X} 5$ & Annual income & 0.121 \\
\hline $\mathrm{X} 6$ & Size of land holding & $0.196^{*}$ \\
\hline $\mathrm{X} 7$ & Farming experience & $0.204^{*}$ \\
\hline $\mathrm{X} 8$ & Material possession & 0.031 \\
\hline $\mathrm{X} 9$ & Extension agent contact & $0.261^{*}$ \\
\hline $\mathrm{X} 10$ & Social participation & $0.241^{*}$ \\
\hline $\mathrm{X} 11$ & Mass media exposure & 0.098 \\
\hline $\mathrm{X} 12$ & Source of information & 0.151 \\
\hline $\mathrm{X}_{13}$ & Innovativeness & 0.088 \\
\hline $\mathrm{X}_{14}$ & Decision making ability & 0.173 \\
\hline
\end{tabular}




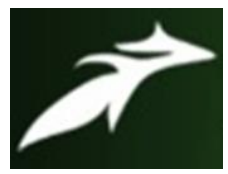

Satyam Kumar et al, International Journal of Advances in Agricultural Science and Technology, Vol.8 Issue.8, August-2021, pg. 60-69

ISSN: 2348-1358

Impact Factor: 6.057

NAAS Rating: 3.77

\begin{tabular}{|l|l|l|}
\hline $\mathrm{X}_{15}$ & Risk bearing capacity & $0.356^{*}$ \\
\hline $\mathrm{X}_{16}$ & Economic motivation & 0.194 \\
\hline
\end{tabular}

NS = Not Significant; $*$ = Significant at 5\%, $* *=$ Significant at $1 \%$.

It could be understood from the table 03, that age, occupation, family size, annual income, material possession, mass media exposure, source of information, innovativeness, decision making ability and economic motivation had non-significant association with the knowledge of the farmers about improved maize cultivation practices. Meanwhile, educational status, size of the land holding, farming experience, social participation and risk bearing capacity had positive and significant association with the knowledge of the farmers about improved maize cultivation practices at 5 per cent level of probability. In addition to this, extension agent contact had positive and significant association with the knowledge level of the farmers about improved maize cultivation practices at 1 per cent level of probability.

Table.04. Association between the independent variables and adoption level of the farmers about improved maize cultivation practices

\begin{tabular}{|c|l|c|}
\hline S. No. & \multicolumn{1}{|c|}{ Characteristics } & 'r' value \\
\hline$X_{1}$ & Age & -0.367 \\
\hline$X_{2}$ & Educational status & $0.501^{* *}$ \\
\hline$X_{3}$ & Occupational status & 0.268 \\
\hline$X_{4}$ & Family size & 0.048 \\
\hline$X_{5}$ & Annual income & $0.335^{*}$ \\
\hline$X_{6}$ & Size of land holding & $0.690^{*}$ \\
\hline$X_{7}$ & Farming experience & 0.015 \\
\hline$X_{8}$ & Material possession & $0.310^{*}$ \\
\hline$X_{9}$ & Extension agent contact & $0.338^{*}$ \\
\hline$X_{10}$ & Social participation & 0.069 \\
\hline$X_{11}$ & Mass media exposure & $0.349^{*}$ \\
\hline$X_{12}$ & Source of information & $0.337^{*}$ \\
\hline$X_{13}$ & Innovativeness & 0.185 \\
\hline$X_{14}$ & Decision making ability & 0.056 \\
\hline$X_{15}$ & Risk bearing capacity & $0.373^{*}$ \\
\hline$X_{16}$ & Economic motivation & 0.103 \\
\hline
\end{tabular}

NS = Not Significant; $*=$ Significant at 5\%, $* *=$ Significant at $1 \%$. 


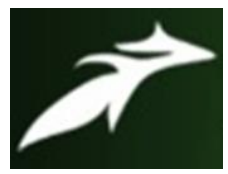

Satyam Kumar et al, International Journal of Advances in Agricultural Science and Technology, Vol.8 Issue.8, August-2021, pg. 60-69

ISSN: 2348-1358

Impact Factor: 6.057

NAAS Rating: 3.77

It could be understood from the table 04, that age, occupation, family size, farming experience, social participation, innovativeness, decision making ability and economic motivation had non-significant association with the adoption level of the farmers about improved maize cultivation practices. Meanwhile, annual income, material possession, extension agent contact, mass media exposure, source of information and risk bearing capacity had positive and significant association with the level of adoption of the farmers about improved maize cultivation practices at 5 per cent level of probability. In addition to this, educational status and size of the land holding had positive and significant association with the adoption level of the farmers about improved maize cultivation practices at 1 per cent level of probability.

\section{Conclusion:}

Majority of the respondents possessed middle level of innovativeness and economic motivation and high level of decision making ability and risk orientation. This shows that the respondent $\mathrm{s}$ are keenly interested on the new technologies. Proper motivation of such respondents will be useful in further dissemination of improved maize cultivation practices, they have the capacity and capabilities to take the improved maize cultivation practice as an enterprise. The overall knowledge of the maize farmers was found under medium level. This is not an appreciable fact. Necessary extension strategies are to be framed to bridge the knowledge gap. The overall adoption of the respondent was found between medium and low category. Though the overall knowledge level of the maize farmers on maize cultivation was to medium level, the medium to low rate of adoption of maize was due to the skeptical nature of the farmers and their traditional attitude. The local extension officials along with scientists should take appropriate knowledge promotional strategies such as training, demonstrations, exhibitions, etc., to impart cent per cent knowledge level and to increase the extent of adoption among the respondents.

\section{References}

[1]. Akshayumar, N.M. Sunilkumar, Ningdalli Mallikarjun and Vidyasagar. (2021). Impact of KVK Trainings on Promotion of Backyard Poultry Farming in Bidar District. Int.J.Curr.Microbiol.App.Sci.10(02):129-133. doi: https://doi.org/10.20546/ijcmas.2021.1002.016

[2]. Kumar, S.A., \& Karthikeyan, C. (2021). Factors Influencing the Utilization of "Uzhavan App" as Perceived by the Farmers in Tamil Nadu. Madras Agricultural Journal, 107(10-12), 1-5.

[3]. Mandal B,K and Dipak, D.E. (2010). Socio-economic profile and communication behaviour of Paddy growers-A study of Banka district. Journal of Communication Studies. 25(4): 121-123. 


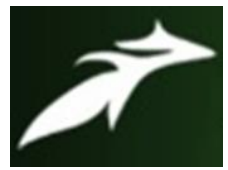

Satyam Kumar et al, International Journal of Advances in Agricultural Science and Technology,

Vol.8 Issue.8, August-2021, pg. 60-69

ISSN: 2348-1358

Impact Factor: 6.057

NAAS Rating: 3.77

[4]. Rajanendra Kumar. (2002). A study on Knowledge and adoption of recommended practices of hybrid maize seed production in Kurnool district of Andhra Pradesh. M.Sc. (Ag.) Thesis, Acharya N.G. Ranga Agriculturel University, Hyderabad, India.

[5]. Sanchita, Brahma, Rupak, Kr. Nath, Kishore Kr. Roy, Ranjit Sarma and Ahmed,Perves. (2020). Production Constraints Faced by Mandarin Cultivators in Kokrajhar District of Assam - A Case Study.International Journal of Current Microbiology Appiled Sciences. 9(6): 81-85. doi: https://doi.org/10.20546/ijcmas.2020.906.010

[6]. Sunil arya D, Singh K. and SinghSatyendar. (2012). Extent of knowledge of change agents and correlation analaysis of varaiables with their communication skill. Indian Research Journal of Extension Education. 12(2): 13-17.

[7]. Venkatalakshmi. K. (2020). Demonstration of Improved Variety and Production Technology of Pulses through Cluster Village Approach.Int.J.Curr.Microbiol.App.Sci. 9(6): 98-103. doi: https://doi.org/10.20546/ijcmas.2020.906.012 